\title{
SUICIDE ATTEMPTS IN MACAPÁ, AMAPÁ, AMAZON REGION, BRAZIL, IN 2018
}

\section{ORIGINAL ARTICLE}

CHAGAS, Jéssica Andréa Silva das ${ }^{1}$

MATOS, Talita de Oliveira ${ }^{2}$

DIAS, Cláudio Alberto Gellis de Mattos ${ }^{3}$

DENDASCK, Carla Viana ${ }^{4}$

OLIVEIRA, Euzébio de ${ }^{5}$

ARAÚJO, Maria Helena Mendonça de ${ }^{6}$

FECURY, Amanda Alves ${ }^{7}$

${ }^{1}$ Medical student. Federal University of Amapá (UNIFAP).

${ }^{2}$ Medical student. Federal University of Amapá (UNIFAP).

${ }^{3}$ Biologist, $\mathrm{PhD}$ in Theory and Research of Behavior, Professor and researcher of the Graduate Program in Professional and Technological Education (PROFEPT), Federal Institute of Education, Science and Technology of Amapá (IFAP).

${ }^{4}$ Theologian, PhD in Psychoanalysis, researcher at the Center for Research and Advanced Studies - CEPA.

${ }^{5}$ Biologist, Doctor in Topical Diseases, Professor and researcher of the Physical Education Course at, Federal University of Pará (UFPA).

${ }^{6}$ Physician, Master in Teaching and Health Sciences, Professor and researcher of the Medical Course at Campus Macapá, Federal University of Amapá (UNIFAP).

7 Biomedical, PhD in Topical Diseases, Professor and researcher of the Medical Course at Campus Macapá, Federal University of Amapá (UNIFAP). 
CHAGAS, Jéssica Andréa Silva das. Et al. Suicide attempts in Macapá, Amapá, Amazon Region, Brazil, in 2018. Revista Científica Multidisciplinar Núcleo do Conhecimento. Year 05, Ed. 06, Vol. 03, pp. 17-35. June 2020. ISSN:2448-0959, Access link in: https://www.nucleodoconhecimento.com.br/health/suicide-attempts

\section{ABSTRACT}

Suicide is the human act of ending one's life. Suicidal attitudes with the intention of death, but without leading to death are called suicide attempts, that is, they are intentional acts of self-harm without the outcome being death. This study analyzed, epidemiologically, the care provided by the Mobile Emergency Service - SAMU / AP related to suicide attempts in 2018 in Macapá / AP. A cross-sectional, descriptive and quantitative research was carried out. Data were collected from 61 records of initial care referring to the events held in 2018, from the SAMU / AP file storage system. This study allowed the expansion of the knowledge of the characteristics of the cases of suicide attempts and consummated suicides that occurred in Macapá / AP, thus enabling the support of professionals to work on interventions with the population in search of the reduction of existing statistics. It is noteworthy that the problem of the lack or notification of cases of suicide attempt performed in an insufficient manner is an important aspect for the weakening of epidemiological information, of network assistance actions and for the realization of territorialization and intersectorality in mental health. Educational actions and public policies that reinforce to the physician and the first aid teams in general the importance of the correct and complete registration of information

Keywords: Suicide, epidemiology, SAMU, Amazonic Region, Brazil.

\section{INTRODUCTION}

For the Pan American Health Organization (OPAS, 2003), suicide is the human act of ending one's life. Suicidal attitudes with the intention of death, but without leading to death are called suicide attempts, that is, they are intentional acts of self-harm without 
the outcome being death (BRASIL, 2008) and WHO calculates that for each suicide consummated there are about twenty people who try it (OMS, 2014).

The Violence and Accident Surveillance System (BRASIL, 2013) presented a survey, carried out in the 24 Brazilian capitals and in the Federal District, with a total record of 272 suicide attempts, of which 171 were female and 101 male, from September to October 2011.

According to the WHO (OMS, 2014), suicide deaths can be prevented if conditions are available to offer help, with prevention as the central component and responsibility of health services as well. Around the world, about 800 thousand people commit suicide every year, which corresponds to a rate of 11.4 deaths for every 100 thousand inhabitants and 1 self-provoked death every 40 seconds. It is estimated that the number of attempts exceeds this rate by up to 10 times.

In Brazil, the methods used for suicide are varied and depend on each place and customs. The most used are hanging, firearms and poisoning (JUNIOR, 2015).

Some factors are known to be related to suicide, such as depressive disorders and alcohol abuse / dependence, but further studies are needed to investigate the social, economic and cultural aspects that may be linked to suicidal behavior (SC) in different regions of Brazil (LOVISI et al., 2009).

In this context, the implementation of the Mobile Emergency Care Service (SAMU) by the Ministry of Health was important, as it provides adequate care to people who are affected by clinical emergencies, including attempts at self-extermination, and can prevent them from dying, already that provide a quick and early care even at the place of the incident (SANTANA et al., 2011).

SAMU provides urgent and emergency care anywhere: homes, workplaces and public roads. With the power of sanitary authority, the regulating physician communicates the occurrence to public hospitals and thus reserves beds for continuity of care (BRASIL, 2006a). The quality of services provided in the emergency sectors is essential to prevent future attempts with a fatal outcome (KAWASHIMA et al., 2014) and must be 
articulated with the other services in the system, allowing the appropriate referral of patients to other competent services (FRANÇA, 2005; AZEVEDO e BARBOSA, 2007) so that each one of these resources collaborates and guarantees comprehensive care to prevent new ST (SUOKAS et al., 2009).

The service flow at SAMU starts from the user's request made through the number 192 , and the occurrence is opened by the medical regulation team. In the regulation room, the doctor responsible for the screening activates one of the USB or USA mobile units, according to the severity of the case (SANTANA et al., 2011).

\section{AIM}

Epidemiologically analyze the calls made by the Mobile Emergency Service - SAMU / AP related to suicide attempts in 2018 in Macapá / AP.

\section{METHOD}

The present study consists of a cross-sectional, descriptive and quantitative research. Data were collected from 61 records of initial care referring to the events held in 2018, from the SAMU / AP file storage system. The study site was the Regulation Center for the Mobile Emergency Care Service (SAMU-AP) based in Macapá / AP, at Rua Jovino Dinoá, Beirol neighborhood, Macapá, Amapá, Amazon region, Brazil.

The information was collected from the SAMU-AP computerized notification system and the storage system of the SAMU Regulation Center, in 2019, in Macapá. Then, all the forms were separated and the data transcribed to an individual form, to be analyzed, without any identification of the subject.

The information was compiled and analyzed using the Excel program, part of the Microsoft Corporation Office suite.

The study was registered at Plataforma Brasil and submitted for analysis by the Research Ethics Committee, following the ethical principles of the Declaration of Helsinki (AMM, 1964) and meeting the ethical considerations set out in resolution 466, 
of $12 / 12 / 2012$, from the National Health Council (CNS), which includes the Regulatory Guidelines and Norms for Research involving human beings, obtaining CAAE 16334919.4.0000.0003.

\section{RESULTS}

Of the 61 records assessed, regarding the month of occurrence, $11(18.03 \%)$ records occurred in August, 9 (14.75\%) in November and 7 (11.48\%) in December, as shown in figure 1.

Figure 1 Distribution of Suicide Attempt cases attended by SAMU - AP, according to the month of occurrence. Macapa, 2018.

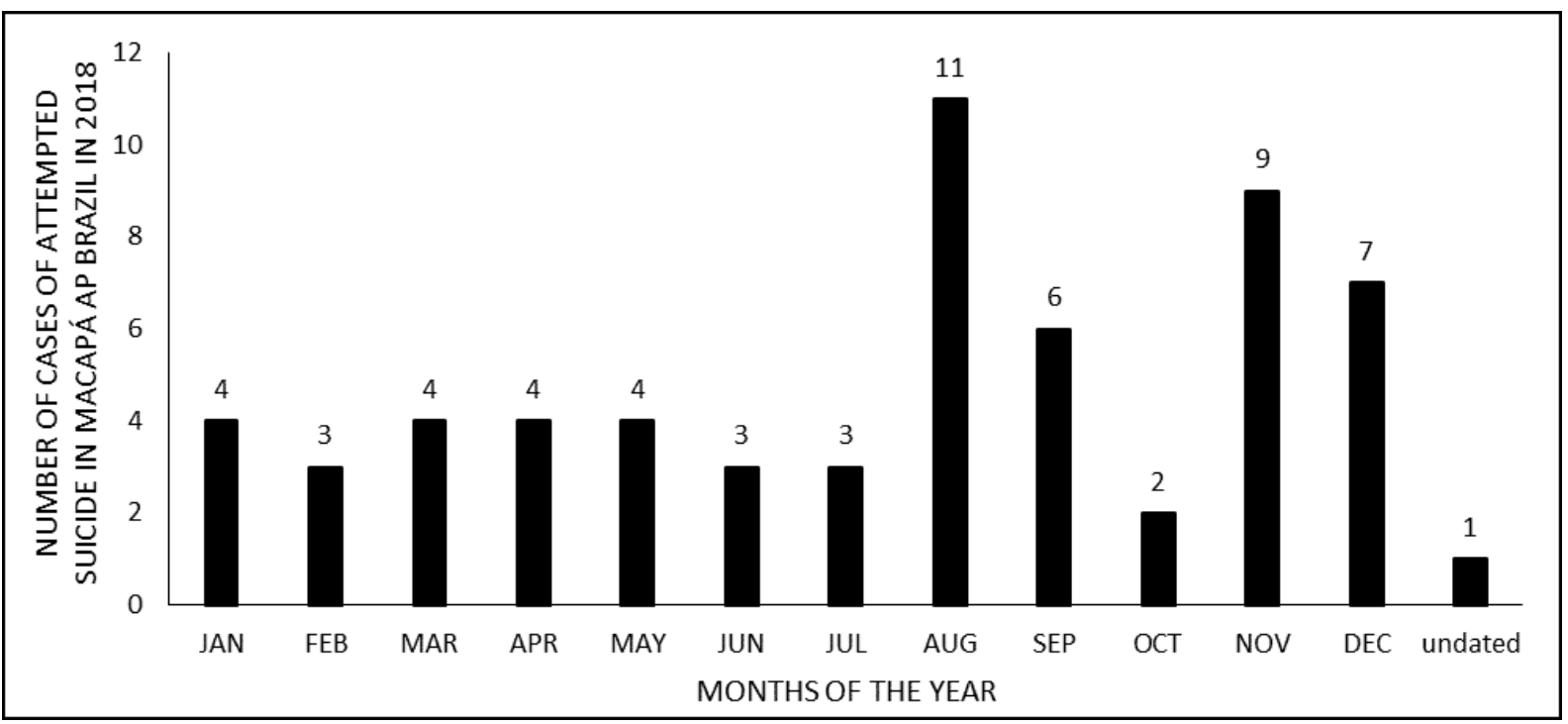

Analyzing the time of occurrences, the largest number of records was during the night, from $18: 00$ to $23: 59$, with a total of 26 cases $(42.62 \%)$, followed by the morning, from $06: 00$ at $12: 00$, with 13 cases $(21.31 \%)$ (figure 2 ). 
Figure 2 Distribution of Suicide Attempt cases attended by SAMU-AP, according to the time of occurrence. Macapa, 2018.

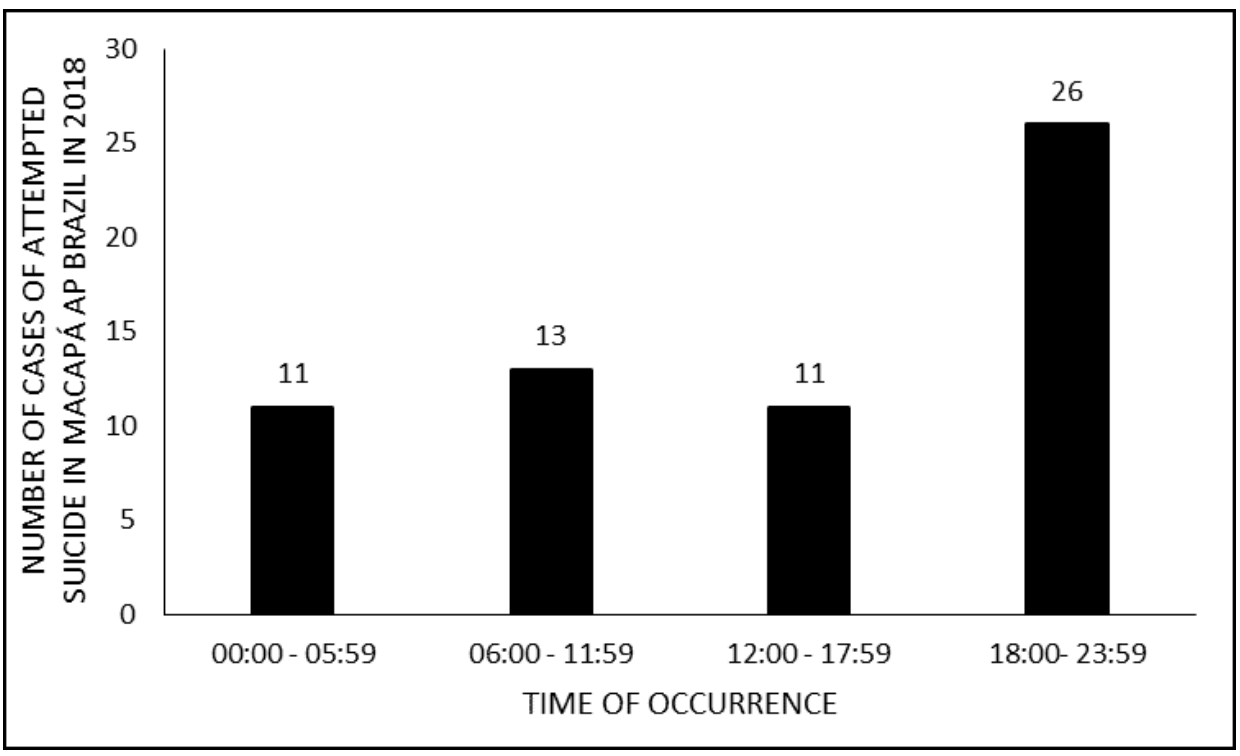

As for the place of request, most attempts at self-harm occurred in the victim's home with 40 notifications (65.57\%), and 12 cases without registration, as shown in figure 3 .

Figure 3 Distribution of Suicide Attempt cases attended by SAMU-AP, regarding the place of request. Macapa, 2018.

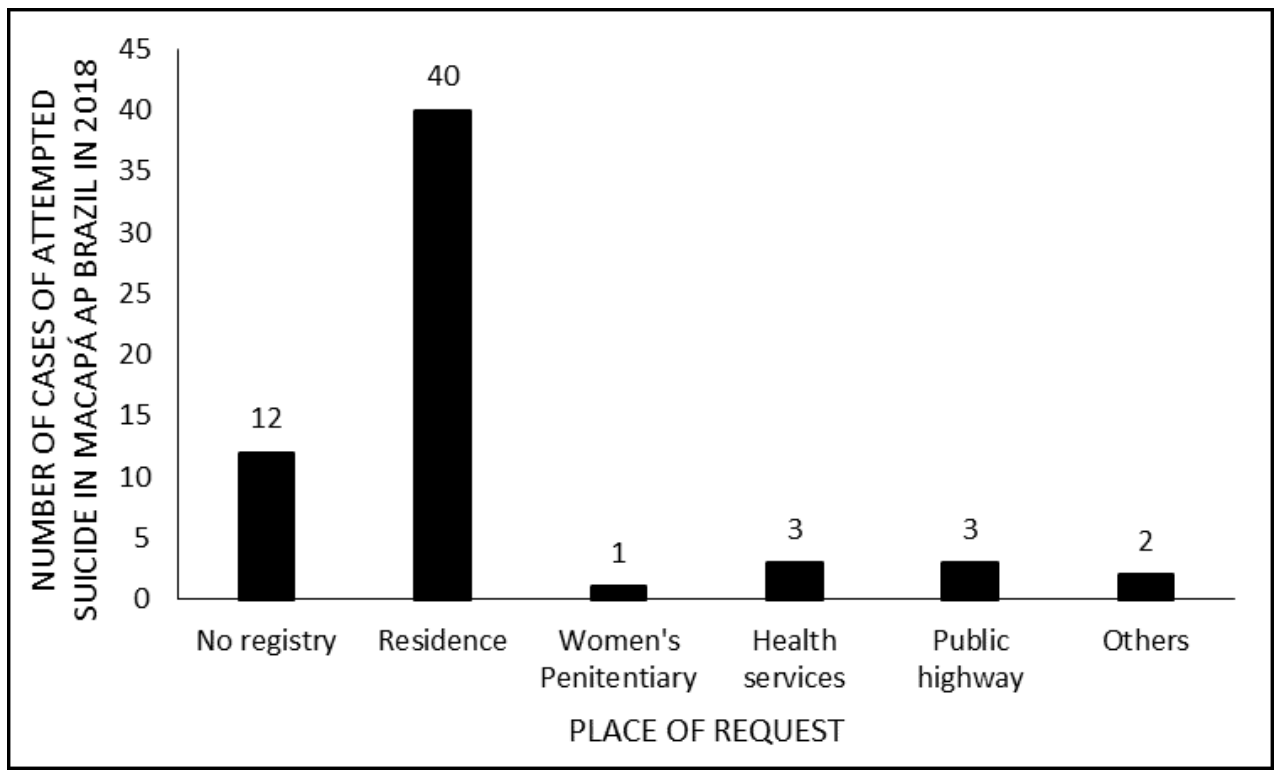


With regard to the type of assistance, the cry for help was the most common call, with $61 \%(51 / 61)$ of the cases analyzed (figure 4$)$.

Figure 4 Distribution of cases of attempted suicide attended by SAMU-AP, regarding the type of assistance. Macapa, 2018.

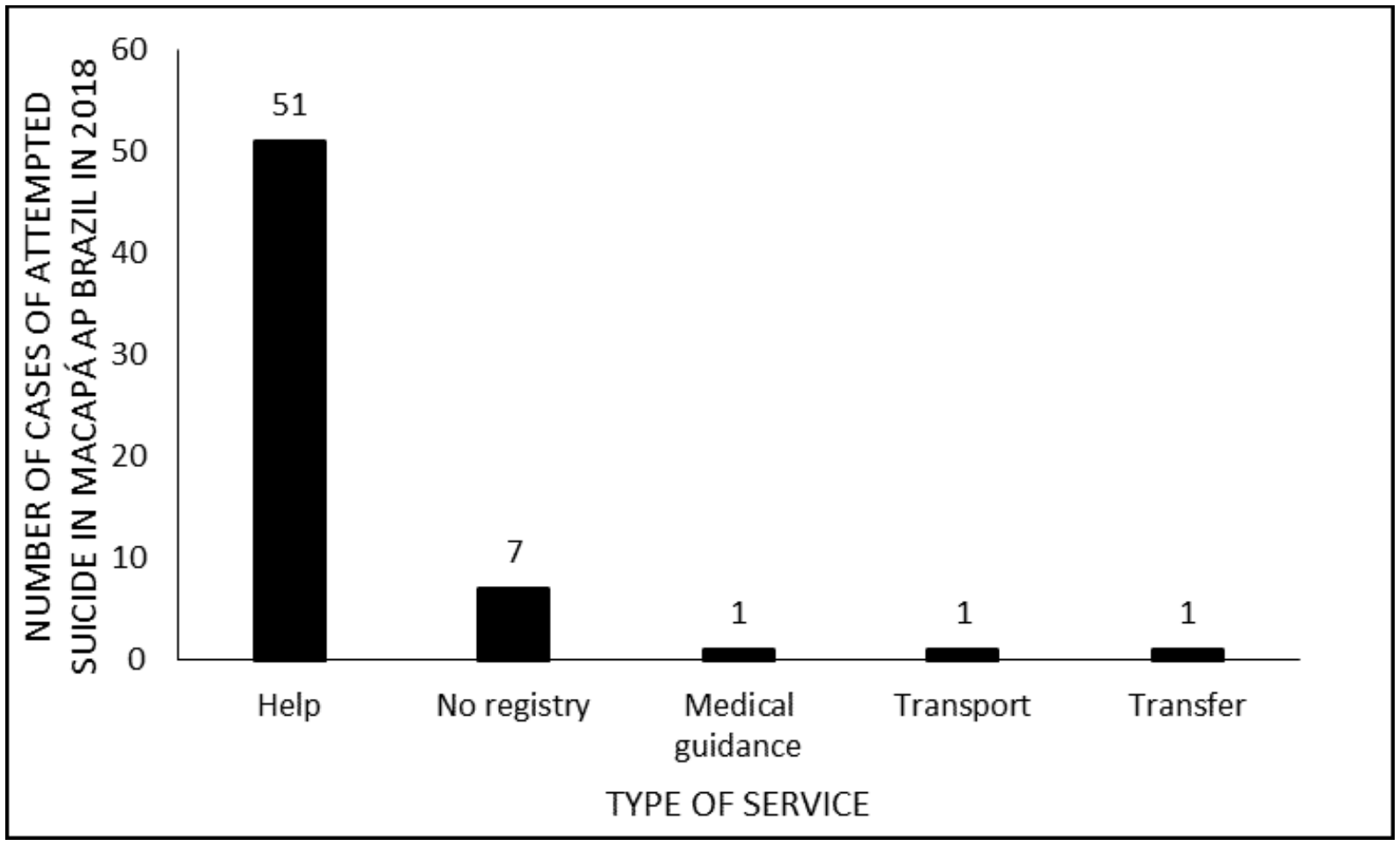

As for the locations where suicide attempts occurred, there was a predominance of the South Zone of Macapá, with 21 cases (34.43\%), including the following locations: Buritizal, São José, Zerão, Jardim Marco Zero, Congós, Muca, Araxá, Emergency Unit (UPA) Zona Sul and Cesein - Center for Socio-Educational Measurement of Male Internment, and, among these, the Congós neighborhood was the most affected. It was also observed the relevance of the North Zone of the city, with 15 cases $(24.6 \%)$, and that SAMU, although based in Macapá, attended 15 cases in the neighboring city, Santana (24.6\%) (Table 1 ). 
Table 1 Distribution of Suicide Attempt cases attended by SAMU-AP, according to the location in Macapá and cases attended in the municipality of Santana,2018.

\begin{tabular}{cccc}
\hline LOCALITY & REGION & $\mathbf{N}^{\circ}$ & $\mathbf{\%}$ \\
\hline \multirow{3}{*}{ MACAPÁ } & North Zone & 15 & 24,6 \\
& West Zone & 5 & 8,2 \\
& Center & 5 & 8,2 \\
& South Zone & 21 & 34,4 \\
SANTANA & $(-)$ & 15 & 24,6 \\
\hline TOTAL & & $\mathbf{6 1}$ & $\mathbf{1 0 0}$ \\
\hline
\end{tabular}

Regarding the characterization of individuals who attempted suicide, the female gender was predominant, with $57.38 \%(35 / 61)$ of the cases, and $31.15 \%(19 / 61)$ corresponding to the male (figure 5). The most affected age group was young people, with 19 cases of adolescents between 14-19 years old (31.15\%) and 11 individuals in the age group of 20 to 25 years old (18.03\%) (figure 6).

Figure 5 Distribution of Suicide Attempt cases attended by SAMU-AP, according to gender. Macapa, 2018.

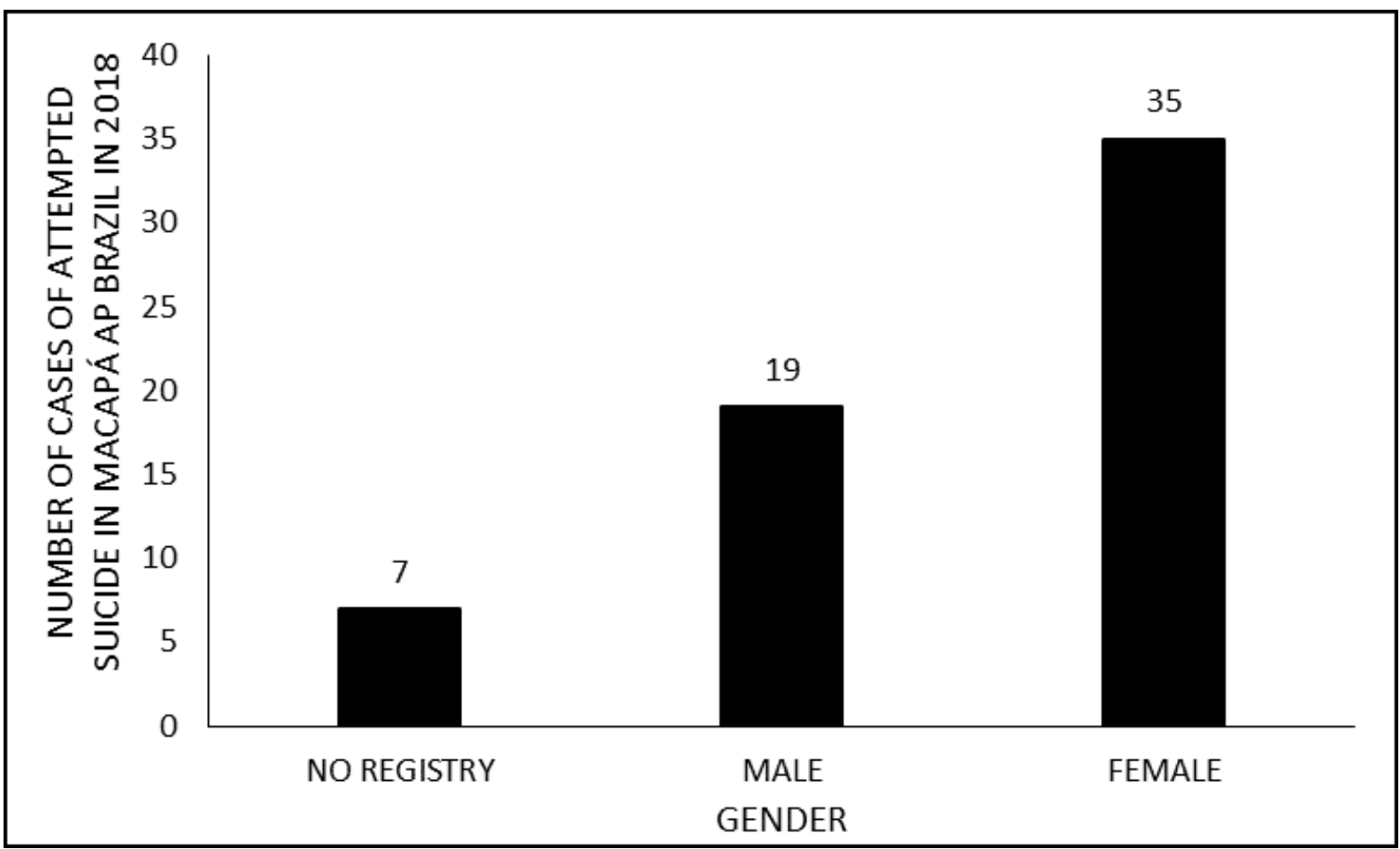


Figure 6 Distribution of Suicide Attempt cases attended by SAMU-AP, according to age group. Macapa, 2018.

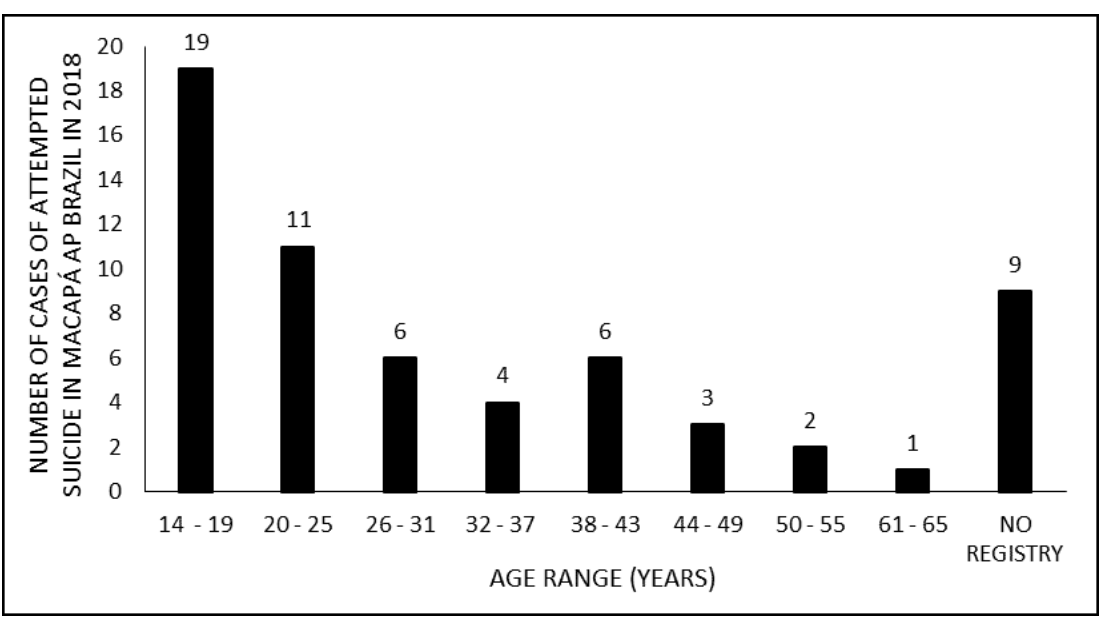

Regarding the mechanisms of suicide attempts, exogenous intoxications ranked first with 22 cases (36.07\%), followed by hanging with 15 (24.59\%) and self-mutilation, with 6 cases $(9.84 \%)$ (figure 7 ). In the analysis of two files, two methods of attempt were found: in the first hanging and exogenous intoxication and in the second self-mutilation and exogenous intoxication. Regarding self-mutilation, it is worth mentioning that all cases occurred due to bladed weapon injuries.

Figure 7 Distribution of Suicide Attempt cases attended by SAMU-AP, according to the attempt mechanism. Macapa, 2018.

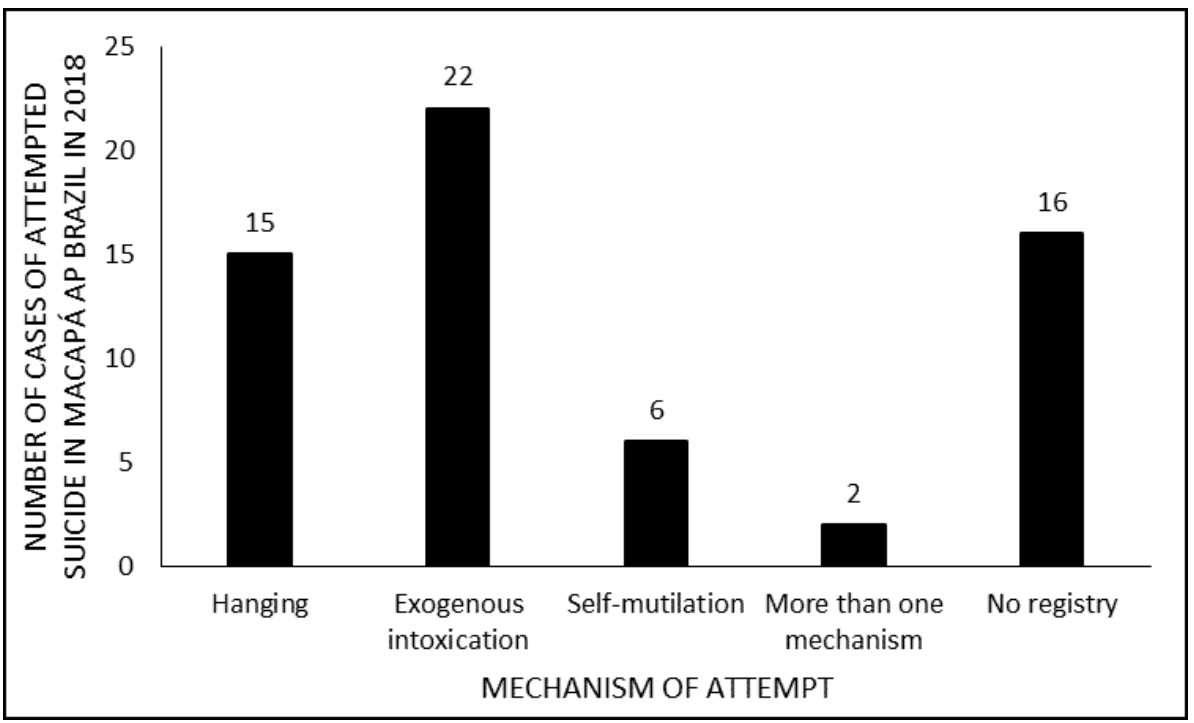


Regarding the support of other institutions, two occurrences (3.28\%) were registered in which the Military Fire Brigade (CBM) was called, one (1.64\%) in which the Military Police (PM) was contacted and one $(1,64 \%)$ where the Basic Support Unit (USB) was recruited, as in this case the Advanced Support Unit (USA) was already providing assistance. Most of the cases (93.44\%) did not have this information recorded (figure 8).

Figure 8 Distribution of Suicide Attempt cases attended by SAMU-AP, according to the need for support. Macapa, 2018.

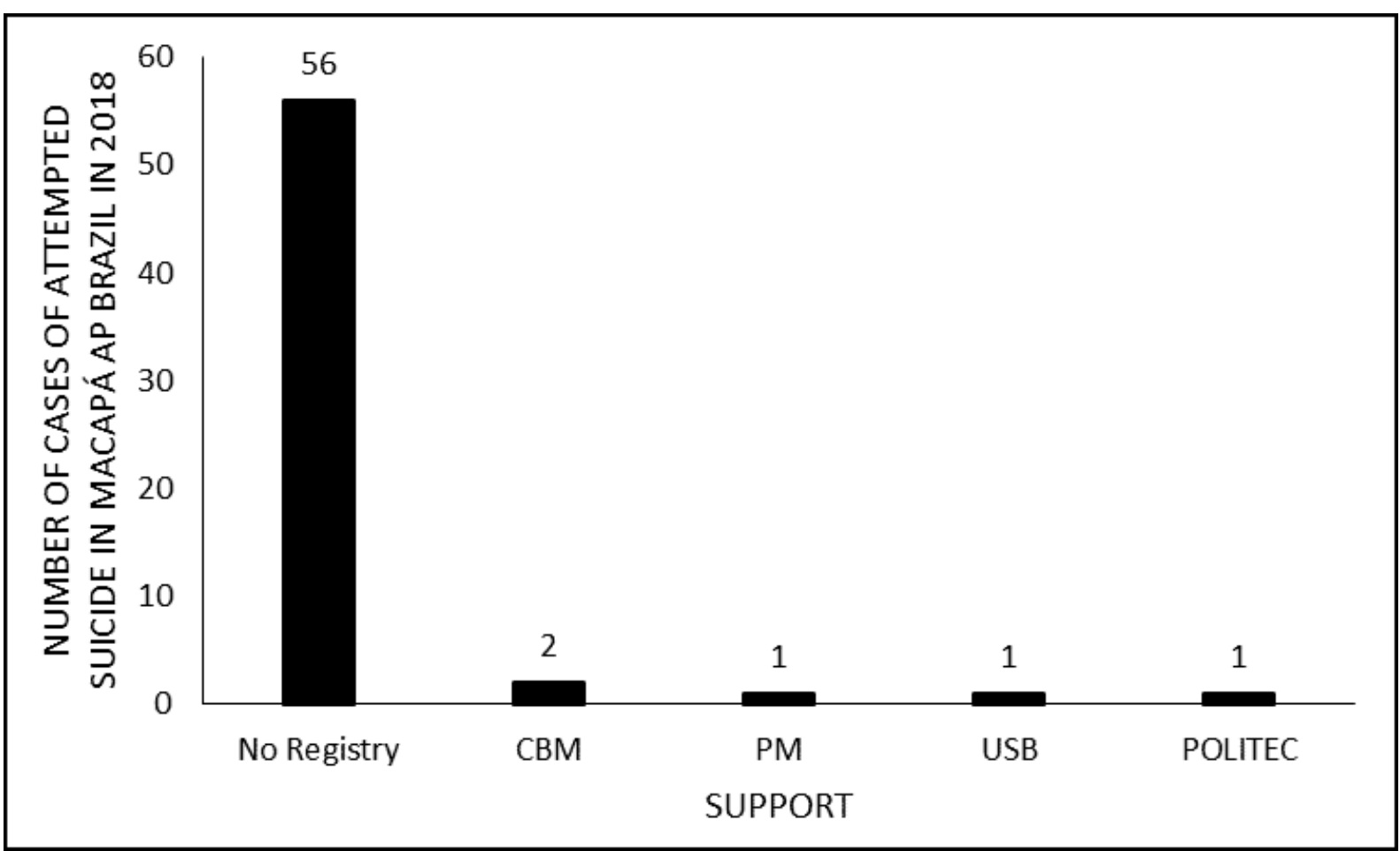

As for the call codes, 8 cases were registered with code 02 , which represents medium priority (urgency), not configuring extreme severity and 8 corresponded to code 3 , which represents maximum priority, emergency (Figure 9). 
Figure 9 Distribution of Suicide Attempt cases attended by SAMU-AP, according to the code used. Macapa, 2018.

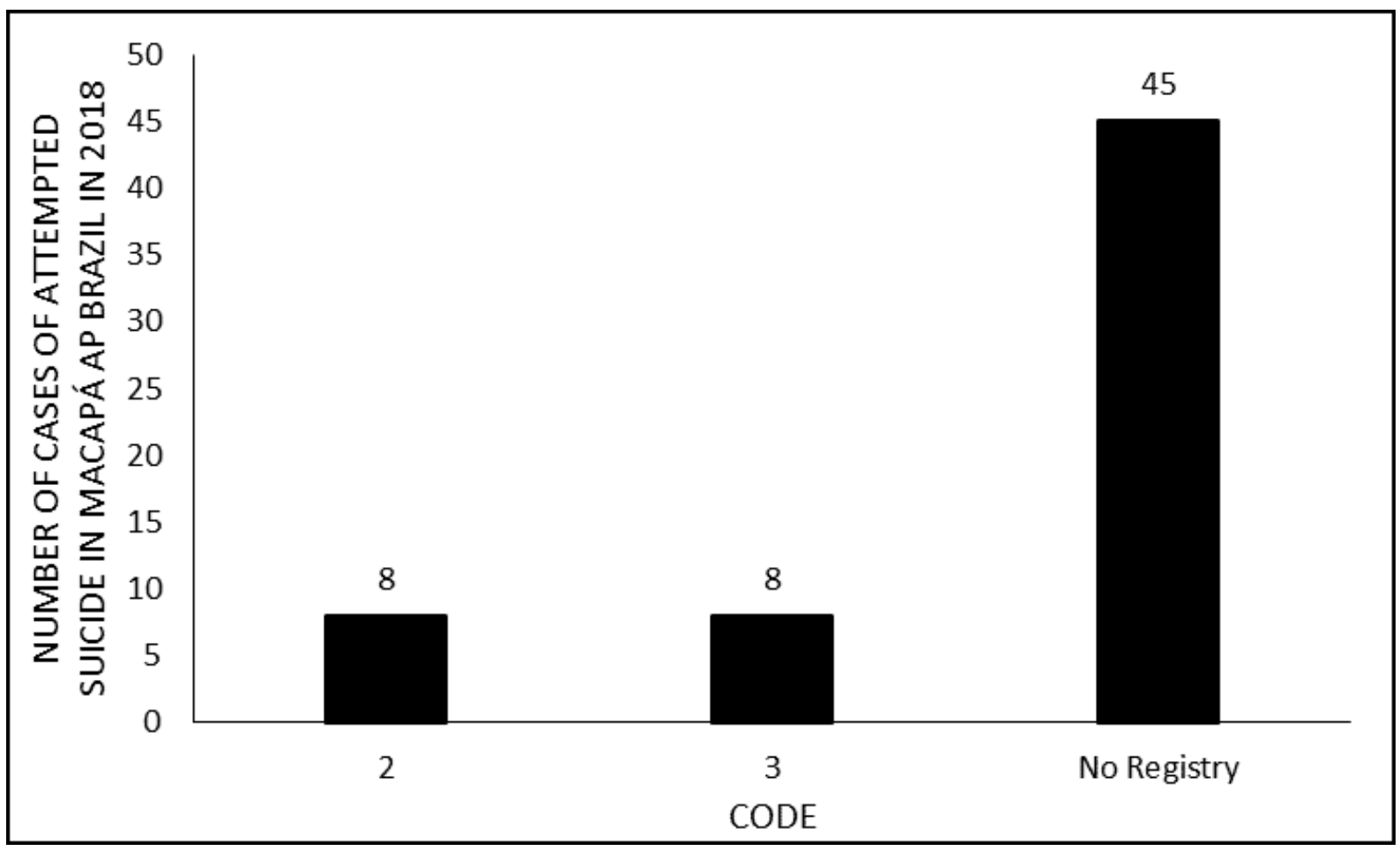

In only 3 records, it was found the record of the ambulance's departure time from the base and arrival time at the occurrence, with an average of 18 minutes remaining.

\section{DISCUSSION}

Most records (18.03\%) occurred in August, which can be explained by the fact that this month is the transition to the hottest period, which occurs in the second half of the year in Amapá (MARQUES et al., 2012; BELÚCIO et al., 2014). This finding is consistent with the fact that suicide attempts or deaths present seasonality throughout the world, with peaks mainly in the transition from the darkest to the lightest seasons (LESTER, 1971). Long-term light can act as an antidepressant and improve mood (PAPADOPOULOS et al., 2005). But in the short term, it can alter the motivational state of individuals and increase the courage to commit suicide. The variation in the level of serotonin can be very fast with the increase in sunlight, which can bring unpleasant feelings (LAMBERT et al., 2002). Researchers also reported a greater 
number of cases in the summer, but stressed that the climatic seasonality of TS is a variable that is difficult to associate in a country of great regional diversity such as Brazil, where the climate has no marked seasons and the seasons are not well defined in all regions (TREVISAN et al., 2013).

Researches showed that increased exposure to sunlight generated an increase in suicide cases (LINS e DE MENEZES, 2018), which may be associated with several sunlight-dependent hormones (such as melatonin, serotonin, tryptophan and cortisol) , responsible for mood regulation (PETRIDOU et al., 2002). It seems that the deregulation of these substances in the body can lead to behavioral changes in individuals (LINS e DE MENEZES, 2018).

It is worth mentioning that this can be a harmless phenomenon for the majority of the population, but for groups that are psychologically vulnerable and predisposed to selfextermination it can be an important risk factor (DEISENHAMMER, 2003).

Regarding the time of occurrence, it was observed that the majority of consultations were carried out at night (18:00 to $23: 59 \mathrm{~h})$ and in the morning (06:00 to $11: 59 \mathrm{~h})$, similar to others works (AVANCl et al., 2005; SOUZA et al., 2011). This finding can be attributed to the ingestion of alcoholic drink mentioned in the collected data, more frequent at night (MENDES e LOPES, 2007), since the consumption of alcohol and / or abuse of other drugs are closely linked to the attempted or consummated suicide , as autopsies of 1,018 suicides pointed out, in which high levels of alcohol concentration were found in the victims' blood ( $\geq 0.1 \mathrm{~g} / \mathrm{kg}$ ) (ZUPANC et al., 2013).

Drug use brings with it greater vulnerability, altered critical judgment and self-control and increased impulsivity, which can trigger suicidal behavior in those predisposed to do so (KLIMKIEWICZ et al., 2012). Alcohol and other additions can increase the risk or interact with depression, thus favoring the appearance of suicidal ideation (WASSERMAN et al., 2005).

Regarding the type of request, the cry for help was the most prevalent, which corroborates with the literature, since in relation to suicidal behavior there is often a cry 
for help, although it is not always clearly conscious, expressed, recognized or welcomed (WHO, 2014; VEDANA et al., 2017).

The cases analyzed in this research were more concentrated in the South Zone, the North Zone and the city of Santana, in the suburbs such as, for example, the Congós neighborhood, consisting of wetlands (MARINHO et al., 2018). A survey conducted in 2006 in Macapá also showed that the majority of people with suicidal behavior (80\%) lived in the suburbs, with lower socioeconomic indices, a lot of inequality and poverty (NEVES, 2007), which is a predisposing factor to suicide (DE FRAGA et al., 2016).

Regarding gender, the prevalence of tentants in this study was female (57.38\%), unlike the others studies (VIDAL et al., 2014; LIMA et al., 2019), in which the male gender predominated, being in accordance with national and global epidemiology (SADOCK et al., 2017; BACHMANN, 2018). As for the deaths reported in this research, there was no predominance of one sex.

This disagreement can be attributed to local epidemiology, as in Macapá women represent the highest percentage with $50.88 \%$ of the population while men correspond to $49.12 \%$ (IBGE, 2010). In addition, in relation to females, the states of Roraima and Amapá were some of those that had the greatest variation in the rate of death by suicide in the period from 2011 to 2015 with 0.9 / 100 thousand inhabitants, according to the Mortality Information (BRASIL, 2017).

Although women are four times more likely to attempt suicide, men are four times more successful (SADOCK e SADOCK, 2007; MOREIRA et al., 2017). This fact may be associated with greater aggressiveness, the intention to die and the use of more lethal means (NOCK et al., 2008). In addition to characteristics such as impulsiveness and competitiveness, men also have greater access to lethal technologies and firearms and carry the role of social gender as the "economic provider" of the home, in a patriarchal culture, being subjected to greater stress regarding unemployment. , impoverishment, despair and mental illness (SANTANA et al., 2011). 
Suicidal behavior in women can be related to traumas experienced in childhood, sexual abuse, marital problems and anxiety disorders, making them more susceptible to new attempts (PIRES et al., 2012; VELOSO et al., 2017). Less lethal methods, religiosity, flexible attitudes towards social skills, performance of roles during life and low prevalence of alcoholism are some of the factors that can be attributed to the lower occurrence of death by suicide among women. They also recognize early signs of risk for depression, mental illness, suicide, seek help in times of crisis and have a greater participation in social support networks (MENEGUEL et al., 2004).

Statistics on domestic and family violence against women in Macapá in 2018, with a record of 1,307 cases, may also be associated with the findings of the present study, due to the intense relationship that this scenario has with financial dependence, low income and low income. educational level of women victims of abuse (AMAPÁ, 2018). This conclusion is also favored due to the fact that most cases of abuse occurred at home, in the evening, predominantly in the neighborhoods of the South Zone of the city, similarly to attempts at self-extermination.

Regarding the age group, the findings are similar to the results of the study which analyzed self-harm in the North Region in the period 2012-2016, and the highest number of deaths recorded was in the age group 20-29 years, also showing itself to be elevated in the 15 to 19 and 30 to 39 age groups (PIRES, 2019). These data are similar to those worldwide, with suicide being the main cause of death among individuals aged 15 to 24 years worldwide (SADOCK et al., 2017). This may mean that the city of Macapá has experienced the regional and national trend of increasing cases of suicide among young people (MACHADO e SANTOS, 2015), since this age group experiences many transformations and issues in the social context in which it is inserted.

Suicide among young people has increased worldwide and in Brazil in recent decades, being the third leading cause of death in this age group in the country. Suicidal behaviors among young people and adolescents involve complex motivations, including broken relationships (PIRES, 2019), depressed mood, substance abuse, 
emotional, family and social problems, family history of psychiatric disorder, family rejection, neglect, in addition to physical abuse and sexual in childhood (ABP, 2014).

Authors point out that the phases of adolescence (12-20 years) and young adults (2040 years) configure periods of personal and social transformations, conflicts arising from their own age, where there is an increase in responsibilities, demands and need to make decisions. The support of others, essential for an emotional balance in this stage of life, is then left aside (SEHNEM e PALOSQUI, 2014).

It is also possible to attribute such results to the current exacerbated use of the internet and social media in childhood and youth, since its unrestrained use is related to several psychic pathologies and to individuals with greater vulnerability, impulsivity and disorders, in addition to social anxiety. , low self-esteem, loneliness, lower levels of physical activity, hostility and aggressive behavior, less subjective happiness and vitality and damage to mental health in general (YOUNES et al., 2016). "The way in which young people use the internet are means that put young people at risk for suicide" (ESCÓSSIA, 2017).

With regard to the suicide attempt mechanism, as well as in several studies (AVANCI et al., 2005; LIMA et al., 2019), there was a predominance of exogenous intoxication as a method, unlike national epidemiology and the Northern region, whose main mechanism is hanging (PIRES, 2019), analogous to the others studies (SEHNEM e PALOSQUI, 2014; VIDAL et al., 2014; CUNHA et al., 2016; D’EÇA JÚNIOR et al., 2019). In some cases, the use of controlled medications was also recorded, in addition to a history of previous psychiatric disorder. Unemployment, distribution and trade of drugs in the country and indiscriminate prescription of psychoactive drugs can be factors that favored the excessive exposure of the population to chemicals (BERNARDES et al., 2010).

Although these morbidities are not the majority in the results found in this study, it is believed that the risk of suicidal behavior throughout life is greater when there is an associated mood disorder, which can increase anxiety (panic disorder, stress disorder) traumatic) or reduce restraint (conduct and antisocial disorders, substance misuse) 
(VASCONCELOS-RAPOSO et al., 2016; BRASIL, 2017). Another Swedish study reinforces that, regardless of the perpetration method (hanging or self-poisoning), antidepressant and / or antipsychotic drugs are the most commonly found in the results of suicide toxicology (JONES et al., 2013).

The predominance of exogenous intoxication as a mechanism of attempt was found in both women and men, however they differed as to the type of substance used, as there was a predominance of the use of medications by women (MOREIRA et al., 2017), and of rodenticides among men. This could be explained by the fact that there is a lesser degree of intentionality among women (DE SOUZA PACHECO et al., 2010). In addition, women attend health services more, tend to seek more basic care and perform more consultations than men (LIMA et al., 2018), which can lead to early diagnoses.

In the literature, the percentages of aggressive behavior and mortality rates are higher among men also because, since youth, women tend not to show this type of behavior significantly (FALCÃO e OLIVEIRA, 2015), which is explained by the different social roles that men and women assume daily.

According to the literature, men use more violent methods, such as hanging, strangulation and suffocation, due to a greater suicidal intention, for knowing information about more lethal means and for having less problems with body image, while women use doses excessive amounts of dangerous substances, or intentional pharmacological autointoxication (VIEIRA et al., 2015).

These findings are corroborated by the Spanish study of 180 suicides, which also showed this difference between men and women in relation to the methods (AZCÁRATE et al., 2015). Still in this direction, a study showed that Iranian patients diagnosed with overdose and suicidal intent were more frequent among women, with the use of psychotropic drugs being more common (ZÖHRE et al., 2015).

It is noteworthy, in this study, that a significant part of $31.4 \%(11 / 35)$ of the women used hanging in the TS, which can be elucidated by the phrase: "the gallows is the 
means more traditionally used by both Brazilians and Brazilians to kill themselves ", although there are many literature that disagree with this premise. It is also noteworthy the significant percentage (26.22\%) of lack of record in the medical records of the means of suicide attempts and death by suicide in both sexes (MINAYO e CAVALCANTE, 2013).

According to the data obtained in this study, the Military Fire Brigade was activated in two occurrences and the Military Police in one, which suggests that the ST involved may have had greater aggravations beyond the patient's clinical condition, a fact reaffirmed by epidemiological issues, geographic and socioeconomic already mentioned, since most of the cases occurred on the outskirts of the city. The absence of this data in 56 records (93.44\%) stands out, which makes greater interpretations difficult.

There is also the classification of the activation and displacement codes of the ambulance. They are: Red and orange code (3) - maximum priority, emergency, immediate and fast movement, light and audible signals on; yellow code (2) - medium priority, urgency, travel in a maximum of 60 seconds, normal speed, with light signals on; and green and blue code (1) - low priority, time for maximum travel according to regulation, normal speed and light signals on (PMC, 2014).

The inadequacy of the records and the inaccurate filling of the data collection instruments generate underreporting (MACENTE e ZANDONADE, 2010). The number of people who commit suicide attempts is much greater than the official notification records (BRANDÃO, 2015), this fact can be elucidated due to the fact that health professionals are still conservative when it comes to this subject and end up masking or not properly registering the events, for religious, social and legal reasons, added to a prejudice already fixed about psychiatric patients and situations that involve them (MINAYO, 1998; BRASIL, 2005). Some studies highlight suicide as the most susceptible to underestimation among external causes (MACENTE e ZANDONADE, 2010). 
In addition, other possible causes for underreporting may occur: (1) professionals are unaware of the importance and procedures for notification; (2) not knowing the list of diseases and conditions subject to surveillance; (3) failure to adhere to the notification; (4) concern about breaking information confidentiality; (5) lack of perception of the public health relevance of the diseases and conditions subjected to surveillance (WALDMAN e JORGE, 1999). In addition, the high demand of the service can deviate functions (DOS SANTOS INÁCIO et al., 2019) and thus not allow professionals to have adequate time to fill out such documents.

The underreporting of compulsory notification diseases is an irregularity that weakens the functioning of the Brazilian health system, generates substantial losses as the underreported diseases constitute a risk to the health of the population. The knowledge of these and their problems are indispensable for the promotion of control actions (SOUZA et al., 2006).

It is essential, therefore, that the SAMU, given the impossibility of carrying out the notification, systematically and organizedly passes on the information related to the service to the referenced unit, to ensure continuity of care and avoid revictimizations (BRASIL, 2016).

\section{CONCLUSIONS}

Although some results are not in agreement with the epidemiology described in the national and worldwide literature, this study allowed for the expansion of knowledge of the characteristics of the cases of suicide attempts and consummated suicides that occurred in Macapá / AP, thus making it possible to subsidize professionals for work on interventions with the population in search of reducing existing statistics.

It is noteworthy that the problem of the lack or notification of cases of suicide attempt performed in an insufficient manner is an important aspect for the weakening of epidemiological information, of network assistance actions and for the realization of territorialization and intersectorality in mental health (BRANDÃO, 2015). 
Therefore, educational actions and public policies are suggested that reinforce to the physician and to the first aid teams in general the importance of the correct and complete registration of information, since these depart from statistical data and resources for the health system, in addition to being support for these professionals in cases of legal relevance.

It is also recommended that urgent and emergency data be used to develop a descriptive baseline for health services and existing epidemiological profiles (BRASIL, 2006b), considering that there is still no official standardized instrument for storing data. information on the occurrences attended (CABRAL e SOUZA, 2008).

\section{REFERENCES}

ABP. Suicídio. Suicídio: informando para prevenir. Brasília DF: CFM/ABP, 2014. AMAPÁ. A violência doméstica e familiar contra a mulher em Macapá: Relatório estatístico- ano 2018. Macapá AP: Ministério Público: 13 p. 2018.

AMM. Princípios éticos para a pesquisa em seres humanos. Helsinque, $1964 . \quad$ Disponível em: < https://www.ifgoiano.edu.br/home/images/Documentos/Pesquisa/CEP/DECLARAODE-HELSINQUE.pdf >. Acesso em: 21 maio 2020.

AVANCI, R. D. C.; PEDRÃO, L. J.; COSTA JÚNIOR, M. L. D. Perfil do adolescente que tenta suicídio em uma unidade de emergência. Revista Brasileira de Enfermagem, v. 58, n. 5, p. 535-539, 2005.

AZCÁRATE, L. et al. Características de los suicidios consumados en Navarra en función del sexo (2010-2013). Anales Sis San Navarra, v. 38, n. 1, p. 9-20, 2015.

AZEVEDO, J. M. R.; BARBOSA, M. A. Triagem em serviços de saúde: percepção dos usuários. Revista Enfermagem UERJ, v. 15, n. 1, p. 33-39, 2007. 
BACHMANN, S. Epidemiology of suicide and the psychiatric perspective. International journal of environmental research and public health. Germany, v. 15, n. 7, p. 1425, 2018.

BELÚCIO, L. P. et al. Radiação solar global estimada a partir da insolação para Macapá (AP). Revista Brasileira de Meteorologia, v. 29, n. 4, p. 494-504, 2014.

BERNARDES, S. S.; TURINI, C. A.; MATSUO, T. Perfil das tentativas de suicídio por sobredose intencional de medicamentos atendidas por um Centro de Controle de Intoxicações do Paraná, Brasil. Cadernos de Saude Pública, v. 26, n. 7, p. 13661372, 2010.

BRANDÃO, W. L. D. O. Comportamento suicida: sociedade, assistência e relações comportamentais. Belém PA: Universidade Federal do Pará, 2015.

BRASIL. Impacto da violência na saúde dos brasileiros. Brasília DF: MS 2005.

. Regulação médica das urgências. Brasília DF: MS 2006a.

. Prevenção do Suicídio: Manual Dirigido a Profissionais das Equipes de Saúde

Mental. Brasília DF, 2006b. Disponível em: < http://portal.saude.gov.br/portal/arquivos/pdf/manual_prevencao_suicidio_saude_me ntal.pdf >. Acesso em: 16 set 2009.

- Manual instrutivo de preenchimento da ficha de notificação/investigação de violência doméstica, sexual e outras violências. Brasília DF, 2008. Disponível em: < http://portal.pmf.sc.gov.br/arquivos/arquivos/doc/01_03_2010_9.48.45.b08c211d429 981fb3856eaf7ec4807b1.doc >. Acesso em: 20 maio 2020.

Sistema de Vigilância de Violências e Acidentes (Viva): 2009, 2010 e 2011. Brasília DF: Ministério da Saúde 2013.

. Protocolos de Intervenção para o SAMU 192 - Serviço de Atendimento Móvel de Urgência. Brasília DF, 2016. Disponível em: < 
http://portalarquivos.saude.gov.br/images/pdsamu/2016/outubro/26/livro-avancado2016.pdf >. Acesso em: 01 jul 2019.

- Suicídio. Saber, agir e prevenir: Boletim Epidemiológico. Brasília

DF, 2017.

Disponível

em:

http://portalarquivos2.saude.gov.br/images/pdf/2017/setembro/21/2017-025-Perfilepidemiologico-das-tentativas-e-obitos-por-suicidio-no-Brasil-e-a-rede-de-atencao-asaude.pdf >. Acesso em: 24 maio 2020.

CABRAL, A. P. D. S.; SOUZA, W. V. D. Atendimento Móvel de Urgência (SAMU): análise da demanda e sua distribuição espacial em uma cidade do Nordeste brasileiro. Revista Brasileira de Epidemiologia, v. 11, n. 4, p. 530-540, 2008.

CUNHA, F. A.; BAPTISTA, M. N.; CARVALHO, L. D. F. Análise documental sobre os suicídios ocorridos na região de Jundiaí entre 2004 e 2014. Salud \& Sociedad, Universidad Católica del Norte, v. 7, n. 2, p. 212-222, 2016.

D’EÇA JÚNIOR, A. et al. Mortalidade por suicídio na população brasileira, 1996-2015: qual é a tendência predominante? . Cadernos Saúde Coletiva, v. 27, n. 1, p. 2024, 2019.

DE FRAGA, W. S.; MASSUQUETTI, A.; GODOY, M. R. Determinantes socioeconômicos do suicídio no Brasil e no Rio Grande do Sul. Encontro De Economia Da Região Sul. Santa Catarina: Universidade Federal de Santa Catarina 2016.

DE SOUZA PACHECO, J. et al. Tentativa de suicídio em mulheres por queimaduras. Revista da Rede de Enfermagem do Nordeste, v. 11, n. 2, p. 152-160, 2010.

DEISENHAMMER, E. A. Weather and suicide: the present state of knowledge on the association of meteorological factors with suicidal behaviour. Acta Psychiatrica Scandinavica, v. 108, n. 6, p. 402-409, 2003. 
DOS SANTOS INÁCIO, A.; TOMASI, C. D.; SORATTO, M. T. Demanda de atendimento em urgência e emergência hospitalar. Enfermagem Brasil, v. 17, n. 6, p. 596-605, 2019.

ESCÓSSIA, F. D. Crescimento constante: taxa de suicídio entre jovens sobe 10\% desde 2002. 2017. Disponível em: < https://www.bbc.com/portuguese/brasil39672513 >. Acesso em: 15 ago 2018.

FALCÃO, C. M.; OLIVEIRA, B. K. F. D. Perfil epidemiológico de mortes por suicídios no município de Coari entre os anos de 2010 e 2013. Revista LEVS/UNESP-Marília, v. 15, p. 44-55, 2015.

FRANÇA, I. G. D. Reflexões acerca da implantação e funcionamento de um plantão de emergência em saúde mental. Psicologia: ciência e profissão, v. 25, n. 1, p. 146163, 2005.

IBGE. Cidades: Macapá, Amapá. 2010. Disponível em: < http://www.cidades.ibge.gov.br/xtras/uf.php?lang=\&coduf=16\&search=amapa >. Acesso em: 26 de junho de 2019.

JONES, A. W.; HOLMGREN, A.; AHLNER, J. Toxicology findings in suicides: concentrations of ethanol and other drugs in femoral blood in victims of hanging and poisoning in relation to age and gender of the deceased. Journal of Forensic and Legal Medicine, v. 20, n. 7, p. 842-847, 2013.

JUNIOR, A. F. O comportamento suicida no Brasil e no mundo. Revista Brasileira de Psicologia, v. 2, n. 1, p. 15-28, 2015.

KAWASHIMA, Y. et al. Prevalence of suicide attempters in emergency departments in Japan: a systematic review and meta-analysis. Journal of affective disorders, $v$. 163, p. 33-39, 2014. 
KLIMKIEWICZ, A. et al. Suicide attempts during heavy drinking episodes among individuals entering alcohol treatment in Warsaw, Poland. Alcohol and alcoholism, v. 47, n. 5, p. 571-576, 2012.

LAMBERT, G. W. et al. Effect of sunlight and season on serotonin turnover in the brain. The Lancet, v. 360, n. 9348, p. 1840-1842, 2002.

LESTER, D. Seasonal variation in suicidal deaths. The British Journal of Psychiatry, v. 118, n. 547, p. $627-628,1971$.

LIMA, A. E. F. et al. Perfil na mortalidade por infarto agudo do miocárdio por idade e sexo no município de Paulo Afonso no estado da Bahia. Revista Rios Saúde, v. 3, n. 1, p. 26-37, 2018.

LIMA, L. C. S. et al. Análise epidemiológica: óbitos por suicídio no estado de Sergipe. Congresso Internacional De Enfermagem. Sergipe: Universidade Tiradentes: 1-4 p. 2019.

LINS, J. G. M. G.; DE MENEZES, T. A. Luz do Sol e Incidência de Suicídio: Evidências de um Desenho de Regressão Descontínua a Partir do Horário de Verão. Encontro ANPEC-Área 12-Economia Social e Demografia Econômica. Rio de Janeiro RJ: ANPEC 2018.

LOVISI, G. M. et al. Análise epidemiológica do suicídio no Brasil entre 1980 e 2006. Revista Brasileira de Psiquiatria, v. 31, n. 2, p. 86-93, 2009.

MACENTE, L. B.; ZANDONADE, E. Avaliação da completude do sistema de informação sobre mortalidade por suicídio na região Sudeste, Brasil, no período de 1996 a 2007. Jornal Brasileiro de Psiquiatria, v. 59, n. 3, p. 173-181, 2010.

MACHADO, D. B.; SANTOS, D. N. D. Suicídio no Brasil, de 2000 a 2012. Jornal Brasileiro de Psiquiatria, v. 64, n. 1, p. 45-54, 2015. 
MARINHO, I. G. et al. Fatores de risco para doenças crônicas não-transmissíveis em moradores no entorno de áreas alagadas na periferia de Macapá, Amapá. Brazilian Journal of Health Review, v. 1, n. 1, p. 148-163, 2018.

MARQUES, D. D. et al. Variação da radiação solar no estado do Amapá: estudo de caso em Macapá, Pacuí, Serra do Navio e Oiapoque no período de 2006 a 2008. Revista Brasileira de Meteorologia, v. 27, n. 2, p. 127-138, 2012.

MENDES, V.; LOPES, P. Hábitos de consumo de álcool em adolescentes. Revista Toxicodependências, v. 13, n. 2, p. 25-40, 2007.

MENEGUEL, S. N. et al. Características epidemiológicas do suicídio no Rio Grande do Sul. Revista de Saúde Pública, v. 38, n. 6, p. 804-810, 2004.

MINAYO, M. C. D. S. A autoviolência, objeto da sociologia e problema de saúde pública. Cadernos de Saúde Pública, v. 14, n. 2, p. 421-428, 1998.

MINAYO, M. C. D. S.; CAVALCANTE, F. G. Estudo compreensivo sobre suicídio de mulheres idosas de sete cidades brasileiras. Cadernos de Saúde Pública, v. 29, n. 12, p. 2405-2415, 2013.

MOREIRA, R. M. M. et al. Análise epidemiológica dos óbitos por suicídio. SANARERevista de Políticas Públicas, v. 16, n. 1, p. 29-34, 2017.

NEVES, S. R. S. Suicídio e Alienação: a vivência cotidiana da desigualdade e da exclusão social. 2007. (Mestrado). Universidade Federal do Pará, Belém PA.

NOCK, M. K. et al. Suicide and suicidal behavior. Epidemiologic reviews, v. 30, n. 1, p. 133-154, 2008.

OMS. Prevención Del suicidio: un imperativo global. Washington USA: OMS, 2014. Disponível em: < www.who.int/mental_health/suicide-prevention/es/ >.

OPAS. Informe Mundial sobre la violência y lasalud: resumen. Washington USA: opas, 2003. 
PAPADOPOULOS, F. C. et al. Exploring lag and duration effect of sunshine in triggering suicide. Journal of affective disorders, v. 88, n. 3, p. 287-297, 2005.

PETRIDOU, E. et al. A role of sunshine in the triggering of suicide. Epidemiology, v. 13, n. 1, p. 106-109, 2002.

PIRES, A. L. T. P. Quantitativo de óbitos por lesões autoprovadas intencionalmente na Região Norte do Brasil no período de 2012 a 2016. Macapá AP: UNIFAP, 2019.

PIRES, M. C. D. C. et al. Estressores na tentativa de suicídio por envenenamento: uma comparação entre os sexos. Trends in Psychiatry and Psychotherapy, v. 34, n. 1, p. 25-30, 2012.

PMC. Campinas: protocolos operacionais normas e rotinas. Campinas SP: SAMU 192, 2014. 108p.

SADOCK, B. J.; SADOCK, V. A. Compêndio de Psiquiatria: ciência do comportamento e psiquiatria clínica. Porto Alegre RS: Artmed, 2007.

SADOCK, B. J.; SADOCK, V. A.; RUIZ, P. Compêndio de Psiquiatria: ciência do comportamento e psiquiatria clínica. Porto Alegre RS: Artmed, 2017.

SANTANA, J. C. B. et al. Caracterização das vítimas de tentativa de autoextermínio atendidas pelo Serviço de Atendimento Móvel de Urgência (SAMU) no município de Sete Lagoas e região. Bioethikos, v. 5, n. 1, p. 84-92, 2011.

SEHNEM, S. B.; PALOSQUI, V. Características epidemiológicas do suicídio no estado de Santa Catarina. Fractal: Revista de Psicologia, v. 26, n. 2, p. 365-378, 2014.

SOUZA, H. C. D. S.; ARCELINO, L. A. M.; TRINDADE, R. F. C. Doenças de Notificação Compulsória: uma análise dos atendimentos ambulatorias no Hospital Universitário Profo Alberto Antunes (HUPAA). 2006. Disponível em: < https://uspdigital.usp.br/siicusp/cdOnlineTrabalhoVisualizarResumo?numeroInscrica oTrabalho=2640\&numeroEdicao=14 >. Acesso em: 21 ago 2019. 
SOUZA, V. D. S. et al. Tentativas de suicídio e mortalidade por suicídio em um município no interior da Bahia. Jornal Brasileiro de Psiquiatria, v. 60, n. 4, p. 294300, 2011.

SUOKAS, J.; SUOMINEN, K.; LÖNNQVIST, J. The attitudes of emergency staff toward attempted suicide patients: A Comparative Study Before and After Establishment of a Psychiatric Consultation Service. Crisis, v. 30, n. 3, p. 161-165, 2009.

TREVISAN, E. P. T.; SANTOS, J. A. T.; OLIVEIRA, M. L. F. D. Tentativa de suicídio de mulheres: dados de um centro de assistência toxicológica do Paraná. Revista Mineira de Enfermagem, v. 17, n. 2, p. 412-423, 2013.

VASCONCELOS-RAPOSO, J. et al. Níveis de ideação suicida em jovens adultos. Estudos de Psicologia, v. 33, n. 2, p. 345-354, 2016.

VEDANA, K. G. G. et al. Emergency nursing experiences in assisting people with suicidal behavior: A grounded theory study. Archives of psychiatric nursing, v. 31, n. 4, p. 345-351, 2017.

VELOSO, C. et al. Violência autoinfligida por intoxicação exógena em um serviço de urgência e emergência. Revista Gaúcha de enfermagem, v. 38, n. 2, 2017.

VIDAL, C. E. L. et al. Perfil epidemiológico do suicídio na microrregião de Barbacena, Minas Gerais, no período de 1997 a 2012. Cadernos Saúde Coletiva, v. 22, n. 2, p. 158-164, 2014.

VIEIRA, L. P.; SANTANA, V. T. P. D.; SUCHARA, E. A. Caracterização de tentativas de suicídios por substâncias exógenas. Cadernos Saúde Coletiva, v. 23, n. 2, p. 118123, 2015.

WALDMAN, E. A.; JORGE, M. H. D. M. Vigilância para acidentes e violência: instrumento para estratégias de prevenção e controle. Ciência \& Saúde Coletiva, v. 4, n. 1, p. 1, 1999. 
WASSERMAN, D. et al. Suicide Prevention Strategies The International Handbook of Suicide Prevention, v. 1, p. 2064-2074, 2005.

WHO. World report on violence and health. Geneva, 2014. Disponível em: < https://www.who.int/violence_injury_prevention/violence/world_report/en/full_en.pdf >. Acesso em: 26 maio 2020.

YOUNES, F. et al. Internet addiction and relationships with insomnia, anxiety, depression, stress and self-esteem in university students: A cross-sectional designed study. PloS one, v. 11, n. 9, 2016.

ZÖHRE, E. et al. Retrospective analysis of poisoning cases admitted to the emergency medicine. Arch Iran Med v. 18, n. 2, p. 117-122, 2015.

ZUPANC, T. et al. Blood alcohol concentration of suicide victims by partial hanging. Journal of Forensic and Legal Medicine, v. 20, n. 8, 2013.

Submitted: June, 2020.

Approved: June, 2020. 